\title{
プリント回路学会* 初代会長
}

\section{安達芳夫 先生}

\section{追悼の辞}

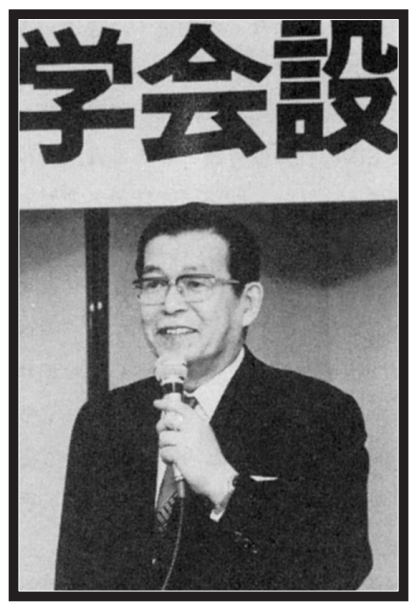

プリント回路学会設立総会での安達先生
平成 21 年 5 月 22 日に, プリント回路学会初代会長の 安達芳夫先生がお亡くなりになられました。

日本の電子産業の黎明期といわれる初期において先鞭 をつけられ，電子産業界を現在の画期的な姿にまで育成 いただいた安達先生の数々のご指導，ご尽力に深甚なる 敬意と感謝を申し上げます。本当に有難うございました。

先生は昭和 19 年, 東京帝国大学第 2 工学部電気工学 科を第 1 期生として卒業されました。アカデミック的な 追求を主体とした大学にあって, 第 2 工学部はテクノロ ジーと産業を結びつけ，学術と産業を結ぶ産学間提携の 中からこそ新しい開発力が作り出されていくとの考え方 を旨とした工学部であったと伺っております。現在の日 本のエレクトロニクス産業界の魁としての先生の想いを 垣間見ることができます。

日本プリント回路工業会の設立は昭和 36 年で, 初代 会長は倉島五郎次氏，2代・佐藤佐寿氏，3代·荒井貞 雄氏，4代·多田博氏，5代 - 中山登氏，専務理事 - 村 上常樹氏と，昭和 61 年までの約 25 年間，歴代会長には まさに手探りの時代から大変なご苦労とご指導により, 工業会を運営していただきました。その間，中小企業近 代化促進法, 社団法人化, 構造改善事業, JPCA ショー, JPCA 規格の整備, JPCA ニュースの発行, 各種調査報告 書, また, 国際化対応としてワールド・コンベンション への参加および開催と論文募集などを実行してまいりま したが，こうした工業会の技術的進歩の受け血として学 会設立の必要性が念願され, 全会長の総意により, 安達 先生にご尽力をお願いすることとなりました。

プリント回路学会設立総会は昭和 61 年, 中山登・学会 設立代表発起人を議長として, 諸議事を承認しつつ進め られました。会長に安達氏, 副会長に中山氏, 常務理事 に村上氏が就任, 引き続き安達会長のもと爾後の議事を 進め, 出席者全員の賛成で総会が無事終了しました。
学会の発足に当たっての安達会長のご挨拶の要点を引 用いたしますと，以下のようになります。

(1)プリント回路に関係した専門の異なる研究・技術者 相互間で，自由に意見を述べ合い，討論し，お互い に切硣玩磨し合う場を作る。

プリント回路に関連ある学問分野は電気・電子工 学, 情報 - 通信工学, 計算機科学, 機械工学, 物 理加工学，化学加工学，有機・無機および複合材料 科学, 金属工学, 物性物理化学, 界面物理学等々, 極めて幅広い分野にまたがっており，総合的にとら えにくい学際的研究を必要とする分野である。こう いったいろいろの分野の方々が目的を一つにして意 見交換をし合うことが，非常に意義深いと考えてい る。

(2)プリント回路関係の技術者の養成, 後進の育成を積 極的に図る。

わが国の如く，物的資源やエネルギー資源の貧弱な 国においては，人材の養成こそが最も重要な課題の 一つである。

(3)わが国がプリント回路の世界でも国際社会の一員と しての責務・役割を果たすために，プリント回路研 究技術者のための学術団体を国内に作る。

(4)最後に, 本学会は次のモットーを掲げて前進した い。

The Institute of the members, by the members, for the members.

（会員の，会員による，会員のための学会）

会員全員が，安達先生のご遺志を継ぎ，日本のエレク トロニクス産業の発展のために努力をしてまいります。

安らかな，ご冥福をお祈り申し上げます。 宇都宮 正（プリント回路学会元会長） 